\title{
EVALUATION OF LOW BACK PAIN BY DIFFERENTIAL SPINAL BLOCK
}

\author{
M. A. Brothers, M.B., B.CH., D.A., And D. C. Finlayson, M.D., F.r.C.P.(c)
}

THE POSSIBLITY of differential spinal block has been appreciated for many years, ${ }^{1}$ but it was not until 1946 that Sarnoff and Arrowood began systematic evaluation of the technique. ${ }^{2}$ Using procaine, they showed that, by giving increasing concentrations $(0.2,0.5$, and $1.0 \%)$ intrathecally, it was possible to block progressively (1) non-myelinated fibres-producing sympathetic blockade and loss of temperature discrimination, (2) myelinated fibres-producing total sensory blockade, and (3) motor fibres.

Subsequently the technique was applied to evaluate the origin of chronic pain in the back and lower limbs., With an increasing number of patients injured at work in whom compensation may be pending, there is a continuing, indeed increasing need for such a diagnostic test to help assess the organic or functional origin of the patient's symptoms.

In this study differential spinal block using lignocaine was carried out with the aim of studying: (a) the capacity of the drug to produce satisfactory blockade using the proposed dosage regimen, and $(b)$ the role of this type of block in the evaluation of "problem" patients with chronic low back pain.

A total of 48 patients with chronic low back pain were referred as problems in diagnosis or management. The majority (40) had already undergone surgery with temporary or no pain relief, and continued to be incapacitated by pain clinically out of proportion to the pathology apparently present. The first 19 patients were referred from the orthopaedic and neurosurgical services after neuropsychiatric evaluation; the remainder were referred directly without such evaluation.

\section{Method}

In each patient the history and physical findings were reviewed and an interview was conducted by the anaesthetist who was to do the block. The patient was questioned with special reference to the type of pain, site, radiation, and subjective reaction to the pain. The test was explained as a method of discovering "which types of nerves are causing the symptoms." In an attempt to further minimize patient bias it was explained that any of the injections made into the back might or might not make the pain disappear and that either continuance or disappearance of the pain after any of these injections was relevant information.

Lumbar puncture was performed in the operating room with the patient unsedated and the pain present or readily reproducible. All punctures were done below the L-2-L-3 interspace to avoid the possibility of cord damage, and using

-Department of Anaesthesia, St. Michael's Hospital, and University of Toronto. 
a \#21 spinal needle. Injections were made at approximately ten-minute intervals using the following solutions: (a) $8 \mathrm{ml}$. of isotonic saline (placebo), (b) $5 \mathrm{mg}$. lignocaine diluted to $8 \mathrm{ml}$. with isotonic saline (sympathetic block), (c) $25 \mathrm{mg}$. lignocaine diluted to $8 \mathrm{ml}$. of isotonic saline (sensory block) and (d) $50 \mathrm{mg}$. lignocaine in 4 or $8 \mathrm{ml}$. of isotonic saline (motor block).

\section{Evaluation}

For evaluation the following observations were made after each injection: ( $a$ ) the patient's subjective evaluation of the pain, $(b)$ the level and type of anaesthesia produced, determined by skin testing.

Sympathetic block was evaluated in 14 of the initial 19 patients by the presence of subjective warmth in the legs, no loss of sensation to pinprick, and the absence of temperature discrimination using an ether-soaked sponge. This was not recorded in the remainder. The demonstrated ability of the technique to produce sympathetic blockade did not add to the evaluation of the patients after this injection. Clinically there were no patients with sympathetic dystrophies in this group, and none experienced pain relief.

Sensory block was assessed by reaction to pinprick and motor block by the onset and extent of muscle paralysis. Previous studies indicate good correlation between the concentration of local anaesthetic agent used and the modality blocked, provided a large enough volume of solution is injected. ${ }^{4}$ However, the most difficult component to assess is that of small non-myelinated fibre sympathetic block. Warmth and vasodilatation in the lower limbs are difficult to measure objectively without recourse to skin thermocouples or observation of the galvanic skin reflex before and after blockade. ${ }^{4,5}$ Temperature discrimination is also carried by small non-myelinated fibres, and testing with an ether sponge to show inability to appreciate cold was found by Ahlgren and Stephen consistently to give levels similar to those indicated by changes in galvanic skin reflex activity. ${ }^{4}$

\section{Results}

Results, as a rule, were clear cut. Patients experiencing pain relief after placebo injection or experiencing no pain relief despite adequate motor blockade and total anaesthesia to a level above that of the pain were judged as having pain of non-organic origin. Partial pain relief with sensory block and complete relief with motor block was more difficult to assess and could very well be considered indicative of pain of mixed origin; that is, organic pain with functional overlay. Those whose pain was relieved by sympathetic or sensory blockade were considered to have symptoms of purely organic origin.

Of the 48 patients in this series, two were eliminated due to a failure to obtain free flow of fluid at lumbar puncture. Of the remaining 46, 27 (59\%) were found to have pain of organic origin. Included in this group were six (13\%) who were relieved only by motor block and who might thus be considered as representing patients with pain of mixed origin. Nineteen ( $41 \%)$ had pain of clearly functional origin. In the initial group of patients referred after neuropsychiatric evaluation the functional-organic pain ratio $(45: 55)$ much resembled that of the overall 
group (19/27, or 41:59). The 31 Workmen's Compensation patients comprised 67 per cent of the group studied and were apportioned similarly in both functional (14, or $45 \%$ ) and organic (17, or 55\%) groups.

The doses of lignocaine selected were adequate to produce differential blockade. Indeed the $50 \mathrm{mg}$. dose in $8 \mathrm{ml}$. used initially for the production of motor blockade was found to produce a block to a higher level than was required for this study. After the first ten patients this dose was given diluted to only $4 \mathrm{ml}$. Five mg. of lignocaine produced sympathetic block to levels between T-10 and L-3, with the average being in the upper lumbar region. Twenty-five mg. produced sensory anaesthesia to levels lying between T-10 and L-3, and $50 \mathrm{mg}$. produced motor block at levels from T-2 to T-8. As noted above, this was considerably higher than necessary for pain evaluation. The smaller dilution volume gave levels of motor blockade to an average of T-8.

Although differential spinal block is a useful diagnostic tool in cases where functional pain cannot be ruled out, there are difficulties attached to performing lumbar puncture and blockade in these patients. There are technical difficulties due to previous surgery and, secondly, many of these patients may have psychogenic pain which may worsen following such a procedure. ${ }^{3}$ Although this latter complication was absent in our group of patients, others did occur. One patient developed severe reactive depression after blockade and another exhibited signs of aseptic meningitis. Six patients had clinically significant falls in blood pressure which were readily controlled by five or ten $\mathrm{mg}$. of methamphetamine given intravenously.

The occurrence of such complications in patients with compensation decisions pending raises the possibility of further litigation and claim problems which cannot be ignored. Despite this risk, differential spinal blockade is, in the opinion of this group, a useful aid in the evaluation of such problem patients.

\section{SUMMARY}

Differential spinal blockade using lignocaine is described as a technique to evaluate patients with chronic low back pain. Successive doses of 5,25 , and 50 $\mathrm{mg}$. of lignocaine in isotonic saline introduced into the subarachnoid space produced results comparable to those obtained with $0.2,0.5$, and 1 per cent procaine. Of 46 patients, 27 were found to have pain of organic origin and 19 of nonorganic origin. The value of differential spinal blockade is discussed.

\section{RÉSUMÉ}

En 1946, Sarnoff et Arrowood ont décrit un bloc spinal différentiel; en se servant de concentrations croissantes de procaïne injectée dans l'espace sous-arachnoïdien, ils pouvaient bloquer progressivement les fibres sensorielles non recouvertes de myéline, les petites fibres à myéline et enfin les grosses fibres motrices à myéline. Récemment, cette technique a été utilisée pour étudier les cas "problèmes" souffrant de douleurs chroniques dans le dos ou dans les membres inférieurs. 
On a pratiqué le blocage spinal différentiel en utilisant la lignocaïne dans le but d'évaluer la puissance de ce produit comme agent de blocage et de plus pour évaluer le rôle de ce bloc pour les cas "problèmes".

Les malades qui sont dits complètement soulagés par une injection de placebo ou qui n'ont éprouvé aucun soulagement par un blocage adéquat ont été classés comme ayant des douleurs d'origine fonctionnelle; ceux dont la douleur a été soulagée par un blocage sensitif ou moteur ont été considérés comme souffrant d'une douleur d'origine organique. Dix-neuf malades étaient du groupe fonctionnel et 27 du groupe organique.

On étudie dans ce travail la technique du bloc et son interprétation.

\section{ACKNOWLEDGMENTS}

We are indebted to Dr. John G. Evans, and to the other members of the orthopaedic and neurosurgical services without whose co-operation and assistance this study would not have been possible.

\section{REFERENCES}

1. Maxon, L. H., ed. Spinal Anaesthesia, ch. 12. New York: Lippincott (1938).

2. Sarnoff, S. S. \& ARrowood, J. G. Differential Spinal Block-Preliminary Report. Surgery 20: $150(1946)$.

3. McColnum, D. E. \& Stephen, C. R. The Use of Graduated Spinal Anaesthesia in the Differential Diagnosis of Pain in the Back and Lower Extremities. Southern Med. J. 57: 410 (1964).

4. Afrgren, E. W.; Stephen, C. R; et al. Diagnosis of Pain with a Graduated Spinal Block Technique. J.A.M.A. 195: 813 (1966).

5. Wanc, G. H. The Galvanic Skin Reflex-A Review of Old and Recent Works from a Physiological Point of View. Am. J. Phys. Med. 36: 295 (1957). 